Kyfiak Vasyl, Doctor of Sciences (Economics), Professor Chernivtsi Institute of Trade and Economics of KNUTE ORCID: 0000-0001-7632-5248

Kyfiak Oleksandr, Ph.D., Associate Professor, Department of Marketing, Innovation and Regional Development of Y. Fedkovich Chernivtsi National University. ORCID: 0000-0003-3689-8548

\title{
FROM CROSS-BORDER COOPERATION TO EUROPEAN INTEGRATION AND GLOBAL ECONOMIC MOVEMENTS
}

The article focuses on changes in the legislation of Ukraine concerning crossborder cooperation and its organizational foundations. According to the survey of scientists, practitioners, representatives of local authorities and public organizations, the definition of «unification of European and regional cooperation with the status of a legal entity" as a socially recognized organizational and legal form of collective socio-economic activity is proposed. Based on the analysis of socio-economic development of a number of regions of Ukraine in 2017, which are territorially located from the Center to the West, it is confirmed that the development of regions in Ukraine occurs from the center to the periphery and the reasons of this situation have been identified. The ways and additional opportunities for the development of crossborder cooperation and its impact on European integration processes and global economic shifts are highlighted. The role of cross-border cooperation in increasing exports and imports of goods and services has been identified on the example of international trade in cross-border regions with the EU countries.

Keywords Relevance of research topic: cross-border cooperation, European integration, social and economic development.

Кифяк Василь, Кифяк Олександр. Від транскордонного співробітництва до євроінтеграції та глобальних

У статті акиентовано увагу на змінах до законодавства Украӥни щодо транскордонного співробітництва та його організаційних основ. За результатами опитування науковиів, практиків, представників місцевих органів влади та громадських організацій, запропоновано визначення «об'єднання єврорегіонального співробітництва зі статусом юридичної особи» як суспільно визнаної організаційно-правової форми колективної соціально-економічної діяльності. На основі аналізу соиіально-економічного розвитку низки областей Украӥни за 
2017 рік, які територіально розташовані від Центру на Захід, підтверджено, що розвиток регіонів в Украӥні відбувається від иентру до периферії та встановлено причини такого стану. Виокремлено шляхи та додаткові можливості розвитку транскордонного співробітництва $і$ його впливу на процеси євроінтеграиії та глобальні економічні зрушення. На прикладі міжнародної торгівлі y прикордонних регіонах з краӥнами ЄС визначено роль транскордонного співробітниитва у нарощуванні обсягів експорту та імпорту товарів і послуг.

Ключові слова: транскордонне співробітнищтво, євроінтеграція, соџіальноекономічний розвиток.

Formulation of the problem. Globalization processes and the simultaneous implementation of administrative reform in Ukraine and the delegation of broad authorities to the united territorial communities and local authorities have significantly actualized the importance of establishing relations between Ukraine and neighboring countries, both at the state and regional levels.

Cross-border links between the adjacent territories of neighboring countries, which have become an effective mechanism for the socio-economic development of the regions on both sides of the border are getting a particular importance.

A powerful instrument in Ukraine's international economic relations with neighboring countries has been the creation of European regions, the functioning of which facilitates the gradual integration of cross-border regions first and then of Ukraine as a whole into the world economic system.

The relevance of this research is also determined by the development and implementation of a single strategic line and a coordinated policy of cross-border economic cooperation throughout Ukraine, which will allow intensive advancement to global economic shifts.

Today, the regions adjacent to the state border are active in not only environmental, cultural, sporting, educational, migration, security spheres, but also in economic, social and other activities. In the West, Volyn, Lviv, Ivano-Frankivsk, Transcarpathian and Chernivtsi regions have borders with the countries of the European Union (EU) - Poland, Slovakia, Hungary and Romania, in the south Odessa region borders with Romania.

Nowadays Ukraine and the European Union are working under four cross-border co-operation programs, which will operate until 2020. In particular, the programs are: Ukraine-Poland-Belarus, Ukraine-Slovakia-Hungary-Romania, Ukraine-Romania and the Black Sea Basin. And as the Director of the Government Office for European Integration stated, «within the priorities of the Association Agreement, in particular, the course of decentralization, we keen to intensify investment, joint economic activities in those regions bordering the EU countries, to promote the development of infrastructure projects that bring Ukraine closer to the creation of European standards of living» [7]. 
Thus, Ukraine's neighborhood with the EU states necessitates the extension of crossborder cooperation in all directions.

Adherence to international imperatives and the objective regularity of moving the center of gravity of the management of socio-economic processes from the national to the regional level encourage the search and expansion of modern forms and methods of cross-border cooperation and adaptation of economic activity to the conditions of international business.

However, despite Ukraine's associate EU membership and strategic partnership between cross-border regions of Ukraine and the EU countries, the socio-economic development of cross-border regions has a significant backlog in many economic indicators. There is a need to identify the causes of such a significant gap between the internal and cross-border regions of Ukraine and conduct a scientific research on identifying problems that will stimulate economic growth and European integration.

Analysis of recent researches and publications. Many foreign and domestic scientists have studied the issues of cross-border cooperation development, its impact on the socio-economic development of cross-border regions, the definition of forms and methods of cooperation. Significant contributions to the study of these issues were made by: Joachim Beck, Birt Wassenberg, Carmen Nastase, Danila Moroshan, O. Garasyuk, V. Evdokymenko, M. Lendel, A. Mazaraki, T. Melnyk, N. Mikula, V. Pyla, T. Tereshchenko, I. Shkola, O. Chmyr and others.

In particular, German professor Joachim Beck and French professor Birt Wassenberg focus on the actual and potential contribution of cross-border co-operation to European territorial cohesion and believe that the practical field of cross-border cooperation outweighs the theoretical, they consider it exemplary [1, 19]. Romanian scholars, Carmen Nastase and Danila Moroshan offer sources of funding for cross-border cooperation [4, p.191-193].

Exploring the impact of globalization processes on the development of international economic relations, including cross-border economic cooperation, Professor A. Mazaraki emphasizes: «International economic relations have developed since the second half of the twentieth century with the significant impact of globalization. Globalization contributes to the integration of international relations at the bilateral and regional levels into a coherent system» [5, p. 200].

However, under current conditions, the legislation of Ukraine on cross-border cooperation has been amended and new forms of cooperation are envisaged. With the creation of Euro-regional cooperation associations with the status of a legal entity [20, Art. 1], there is an objective need to expand the cross-border cooperation not only in the interests of cross-border regions, but also its increased impact on integration processes and global economic shifts.

Scientific substantiation of ways of expanding cross-border cooperation based on updated legislation and research of the impact of economic growth on integration processes. In order to do this there is a need to clarify the essence of the concept of 
«unification of Euro-regional cooperation with the status of a legal entity». It is important to systematize scientific approaches to problems solving of cross-border regions development and establishing reasons for their lagging behind in the socioeconomic development of the central regions of Ukraine as well as to explore the international trade and economic relations of cross-border regions and to determine the impact of cross-border cooperation.

Presenting main material. A prerequisite for cross-border activity is compliance with the law, which consists in the «formation of legal and institutional support for cross-border cooperation at the international, national, local and regional levels» $[8$, p. 31]. According to the Law of Ukraine, cross-border cooperation is defined as «joint actions aimed at establishing and deepening of economic, social, scientific, technological, environmental, cultural and other relations between the subjects and participants of such relations in Ukraine and the respective entities and participants of such relations with of neighboring states within the competence defined by their national legislation «[20, Art. 1].

At the same time, Birt Wassenberg states that borders are the scars of history and overcoming them is the goal of regional cross-border co-operation in Europe [19], which is extremely important both for cross-border regions of Ukraine and for the whole country.

In order to remove the barrier functions of the border, amendments to the Law of Ukraine «On Cross-Border Cooperation» have been introduced in 2018. They will stimulate the creation of «associations of cross-border cooperation entities of Ukraine and relevant entities of neighboring Member States of the European Union with legal status persons in accordance with the national legislation of the Member State of the European Union in the territory it is located «[20, Art.1]

According to the surveys of leading scientists, practitioners, representatives of public organizations and regional authorities that are researching, directly participate in cross-border cooperation, coordinate and promote its development, the concept of «unification of Euro-regional cooperation with the status of a legal entity» has different interpretations.

For example, business leaders believe that «unity of Euro-regional cooperation with the status of a legal entity» is a voluntary association of commercial and noncommercial legal entities, regardless of the form of ownership, whose main purpose is to promote business activity in cross-border regions, simplified creation of joint ventures, and development of small and medium-sized enterprises. Cross-border business centers, business incubators, sectoral or territorial clusters should be created based on Euroregional cooperation, and «poles of economic growth» should be formed.

Public representatives consider the main point in the activity of «integration of Euro-regional cooperation with the status of a legal entity», the development and implementation of joint projects, the formation of programs and strategies of cross- 
border cooperation, joint activities, promotion of Euro-regions, creation and promotion of their brand, etc.

Taking into account these and other opinions of practitioners, public activists, representatives of local authorities, as well as that territorial community, their representative bodies and associations, local executive bodies, public organizations and other legal entities may be participants of cross-border cooperation. We believe that «unification of Euro-regional cooperation with the status of a legal entity» is a socially recognized organizational and legal form of collective socio-economic activity created in accordance with national law of the territory it is located.

The Association Agreement between Ukraine and the European Union provides a wide range of opportunities for the modernization of regional policy and the implementation of cross-border cooperation [18, Art. 446-448]. In the State Strategy of Regional Development for the period up to 2020 and the State Program of CrossBorder Cooperation Development for 2016-2020 [3, 2], cross-border cooperation is generally defined as a tool for enhancing the competitiveness of border territories and a factor in accelerating integration processes.

In 2012, I. Shkola stated: «the development of integration processes leads to the strengthening of regionalization processes, enhancing the role and importance of cross-border regions of the country as international economic agents in the context of forming and maintaining the competitiveness of national economies, strengthening good neighborly relations and creating conditions for coordination actions in the field of integration of economies of neighboring countries $«[9, p .6]$.

According to separate indexes, the analysis of socio-economic development of a number of regions of Ukraine for 2017 shows that regions located from the Center to the West, with the exception of Lviv, with the approximation to the borders with the EU countries, are less economically developed and the inhabitants of these regions less socially protected (Table 1) [16, p. 507-518].

Table 1

\section{Analysis of socio-economic development of particular regions of Ukraine in 2017}

\begin{tabular}{|l|c|c|c|c|c|c|}
\hline Regions of Ukraine & $\begin{array}{c}\text { GRP per } \\
\text { person / } \\
\text { UAH }\end{array}$ & $\begin{array}{c}\text { Monthly } \\
\text { average } \\
\text { wage / UAH }\end{array}$ & $\begin{array}{c}\text { Income per } \\
\text { person / UAH }\end{array}$ & $\begin{array}{c}\text { Costs per } \\
\text { person / } \\
\text { UAH }\end{array}$ & $\begin{array}{c}\text { Consumer } \\
\text { Price Index, } \\
\%\end{array}$ & $\begin{array}{c}\text { Level of } \\
\text { unemploy- } \\
\text { ment, } \%\end{array}$ \\
\hline 1. Kyiv & 78075 & 7188 & 50321 & 73202,0 & 114,0 & 6,5 \\
\hline 2. Vinnytsia & 48000 & 6121 & 43725 & 57516,9 & 112,3 & 10,7 \\
\hline 3. Zhytomyr & 39560 & 5836 & 41787 & 57295,3 & 113,8 & 10,8 \\
\hline 4. Khmelnytsk & 41290 & 5938 & 42350 & 54095,9 & 113,4 & 8,9 \\
\hline 5. Ternopil & 30299 & 5554 & 35211 & 50325,3 & 114,0 & 11,9 \\
\hline 6. Ivano-Frankivsk & 38000 & 6074 & 39326 & 56686,5 & 113,5 & 8,5 \\
\hline 7. Lviv & 58200 & 6391 & 44194 & 59854,2 & 112,4 & 7,5 \\
\hline 8. Volyn & 35442 & 5849 & 38069 & 56592,0 & 114,6 & 12,5 \\
\hline 9. Chernivtsi & 23435 & 5621 & 35403 & 49775,7 & 112,4 & 8,4 \\
\hline 10. Zakarpattia & 25572 & 6355 & 33282 & 47723,2 & 113,3 & 10,5 \\
\hline
\end{tabular}

Source: Statistical Yearbook of Ukraine for 2017. 
Comparison of these and other indicators confirms that the socio-economic development of regions in Ukraine occurs from the center to the periphery. The main reasons for this situation are that cross-border regions of Ukraine, due to their distance from the center, in most of them developed with slower pace, were industrialbackward, and had poor transport links with the center, which led to a decrease in economic efficiency of production and competitiveness of products. Another reason for the gap in socio-economic development between the western cross-border and central regions of Ukraine is active labor migration. According to the State Migration Service and the State Border Guard Service, on January 1, 2019, 3.2 million citizens of Ukraine are permanently employed abroad. Another 7-9 million people work temporarily [10]. These are mainly residents of cross-border areas.

However, «despite the fact that cross-border economic systems are often identified as peripheral and problematic, they are characterized by a high level of communication ability, since they have the ability to use both internal and external resources for development» [17, p. 15].

Today, in the context of administrative-territorial reform and decentralization, cross-border cooperation creates additional opportunities for mobilizing resource potential in cross-border regions of Ukraine, accelerating their socio-economic development and improving the standards of living.

Important place in expanding cross-border economic cooperation is given to international trade in competitive goods and services, including markets of crossborder regions of the neighboring countries. According to T. Melnyk and K. Pugachevska, «our country is significantly inferior to GDP per capita and per capita exports to European countries. At the same time, Ukraine takes a rather active part in the international division of labor due to the higher export quota» [6, p. 212].

Research on international trade and economic relations in cross-border regions shows an increase in international trade, where cross-border cooperation is becoming increasingly important. The Carpathian, Upper Prut, Bug, and Lower Danube Euroregions play a special role in the growth of cross-border trade.

On the example of foreign trade activity of cross-border regions of Ukraine, which have borders with the EU countries, the dynamics of export-import operations for 2013-2017 was analyzed (Table 2), and it is established that the volume of exports of goods and services in 2017 exceeds $\$ 545$ million . Compared to 2013, imports of goods and services decreased by $\$ 3,139.5$ million over the same period [11, p. 585585,12 , p. $576-577,13$, p. $561-562,14$, p. $553-554,16$, p. 532-533]. The ratio of exports of imports of goods and services is 1,088 , which generally confirms the positive foreign trade balance in this group of regions. 


\section{International trade of goods and services in the regions of Ukraine that have borders with the EU (million \$)}

\begin{tabular}{|l|c|c|c|c|c|c|c|c|c|c|}
\hline $\begin{array}{l}\text { Regions of Ukraine } \\
\text { which have borders } \\
\text { with EU }\end{array}$ & \multicolumn{2}{|c|}{2013} & \multicolumn{2}{c|}{2014} & \multicolumn{2}{c|}{2015} & \multicolumn{2}{c|}{2016} & \multicolumn{2}{c|}{2017} \\
\cline { 2 - 11 } & Export & Import & Export & Import & Export & Import & Export & Import & Export & Import \\
\hline Volyn & 686,4 & 1131,4 & 745,7 & 786,0 & 683,5 & 638,8 & 662,7 & 1148,2 & 752,7 & 1359,9 \\
\hline Lviv & 1686,6 & 2769,1 & 1716,4 & 2555,4 & 1576 & 1498,1 & 1669,3 & 1779,4 & 2056,3 & 2240,2 \\
\hline Ivano-Frankivsk & 540,2 & 612,7 & 533,3 & 504,7 & 418,4 & 307,7 & 627,6 & 423,9 & 720,1 & 653,2 \\
\hline Zakarpattia & 1592,4 & 2110,9 & 1584,7 & 1767,8 & 1283,3 & 1032,4 & 1395,9 & 1159,2 & 1703,3 & 1363,6 \\
\hline Chernivtsi & 142,3 & 160,5 & 144,5 & 112,9 & 128,8 & 80,2 & 139,7 & 97,3 & 174,8 & 115,1 \\
\hline Odesa & 2806,7 & 3707,3 & 2800,7 & 2296,1 & 2624,4 & 1099,8 & 2306,1 & 1554,4 & 2592,4 & 1620,4 \\
\hline Total & 7454,6 & 10491,9 & 77525,3 & 8022,9 & 6714,4 & 4657,0 & 6801,3 & 6162,4 & 7999,6 & 7352.4 \\
\hline
\end{tabular}

Source: Statistical Yearbooks of Chernivtsi Region for 2013,2014,2015,2016,2017 (separate comparisons by regions of Ukraine)

At the same time, the largest export of goods and services grew to such neighboring countries as Poland, Hungary, Romania and Slovakia and in total amounted to \$5478.1 million in 2017 [15, p. 393, 399].

At the same time, the globalized world has begun to rapidly develop the digital economy and use artificial intelligence in predicting socio-economic development, which will inevitably lead to deeper integration not only of cross-border regions but also of individual countries and changes in the international division of labor.

In cross-border regions, digital technologies are more likely to penetrate and leverage joint ventures, build partnerships to streamline and automate business processes, increase productivity, and improve communication.

Lack of scientific research and the obvious practical importance of cross-border cooperation in European integration processes, necessitate further comprehensive study of the development of cross-border cooperation through the prism of national interests.

Conclusion. Consequently, the results of the study show that cross-border cooperation is an important way of realizing Ukraine's national interests, and crossborder regions, using their opportunities effectively, can significantly improve their socio-economic status and facilitate European integration processes.

The prospects for cross-border cooperation with EU regions depend on finding and making optimal decisions by the efforts of central and local authorities to formulate an appropriate economic cooperation policy with each country, taking into account the differences that exist on both sides of the border. 


\section{REFERENCES}

1. Beck Joachim and Wassenberg Birte. Vivre et penser la coopération transfrontalière (Volume 6) : Vers une cohésion territoriale? Stuttgart: Franz Steiner Verlag, 2014. 377 p.

2. Derzhavna programa rozvytku transkordonnogo spivrobitnytstva na 20162020 roky // Zatverdzheno Postanovoiu Kabinetu Mininstriv Ukrainy vid 23 serpnia 2016 \# 554 [State Program for the Development of Cross-Border Cooperation for 2016-2020 // Approved by the Decree of the Cabinet of Ministers of Ukraine of August 23, 2016 No. 554]

3. Derzhavna strategiia regionalnogo rozvytku na period do 2020 roku // Zatverdzheno Postanovoiu Kabinetu Ministriv Ukrainy vid 6 serpnia 2014 \# 385 [State strategy for regional development for the period up to 2020 // Approved by the Decree of the Cabinet of Ministers of Ukraine of August 6, 2014 № 385.]

4. Kyfiak V., Năstase C. (2017) Forecasting of cross-border regions development : scenario approach / ed. by: Vasyl Kyfiak, Carmen Năstase. - Suceava: Editura Universităţii «Ştefan cel Mare».

5. Mazaraki A.A., Sivova T.U. (2019). Mizhnarodni ekonomichni vidnosyny v umovah globalizatsii [International economic relations under the conditions of globalization]. Materialy naukovo-praktychnoi Internet konferentsii «Mekhanizmy ta strategii rozvytku gospodariuuchykh subektiv v umovakh integratsiinykh protsesiv» Materials of a scientific and practical INTERNET-conference «Mechanisms and strategies of development of economic entities under the conditions of integration processes», Kharkiv, 19 February, 2019. [in Ukrainian]. Retrieved from: https://dspace.uzhnu.edu.ua/jspui/bitstream/lib/23679/1/Thesis_WSSG_2019.PDF\#pa $\mathrm{ge}=200$

6. Melnyk T.M., Pugachevska K.S. (2018). Perspektyvy rozvytku eksportu Ukrainy v umovakh evrointegratsii [Prospects for development of Ukrainian exports in the context of European integration]. Zhurnal Evropejskoi integratsii - Journal of European Integration. TNEU. Vol.17. \#2 (65). April - June. P. 208-224.

7. Novi programy prykordonnogo spivrobitnytstva $\mathrm{z}$ ES peredbachaut finansuvannia blyzko $350 \mathrm{mln}$ evro /Uriadovyi portal/[New programs of cross-border cooperation with EU investigate funding of about $€ 350 \mathrm{mln} /$ Government portal/], Retrieved from: https://www.kmu.gov.ua/ua/news/248174975

8. Pyla V.I., Chmyr O.S., Garasiuk O.A.,Tereshchenko T.V. (2006). Suchasna regionalna polityka I transkordonne spivrobitnytstvo [Modern economic policy and cross-border cooperation] Khmelnytskyi KhUUP, $412 \mathrm{p}$.

9. Shkola I.M, Babinska O.V. (2012). Transkordonne spivrobitnytstvo [Crossborder cooperation]. Chernivtsi, «Prut». 453p. 
10. Skilky ukraintsiv pratsyue za kordonom [How many Ukrainians work abroad]. Retrieved from: https://www.the-village.com.ua/village/city/city-news/ 280109-skilki-ukrayintsiv-pratsyuyut-za-kordonom

11. Statystychnyi shchorichnyk Chernivetskoi oblasti za 2013 rik // Okremi porivniannia za regionamy Ukrainy [Statistical Yearbook of Chernivtsi region for 2013 // Individual comparisons by region of Ukraine]. Chernivtsi, 2014. 595 p. [i Ukrainian]

12. Statystychnyi shchorichnyk Chernivetskoi oblasti za 2014 rik // Okremi porivniannia za regionamy Ukrainy [Statistical Yearbook of Chernivtsi region for 2014 // Individual comparisons by region of Ukraine]. Chernivtsi, 2015. 586 p. [i Ukrainian]

13. Statystychnyi shchorichnyk Chernivetskoi oblasti za 2015 rik // Okremi porivniannia za regionamy Ukrainy [Statistical Yearbook of Chernivtsi region for 2015 // Individual comparisons by region of Ukraine]. Chernivtsi, 2016. 571 p. [in Ukrainian]

14. Statystychnyi shchorichnyk Chernivetskoi oblasti za 2016 rik // Okremi porivniannia za regionamy Ukrainy [Statistical Yearbook of Chernivtsi region for 2016 // Individual comparisons by region of Ukraine]. Chernivtsi, 2017. 563 p. [i Ukrainian]

15. Statystychnyi shchorichnyk Ukrainy za 2017 rik [Statistical Yearbook of Ukraine for 2017]. K.: - 2018. 540 p. [in Ukrainian]

16. Statystychnyi shchorichnyk Chernivetskoi oblasti za 2017 rik // Okremi porivniannia za regionamy Ukrainy [Statistical Yearbook of Chernivtsi region for 2017 // Individual comparisons by region of Ukraine].Chernivtsi, 2018. 543 p. [i Ukrainian]

17. Stsenarne prognozuvannia rozvytku prykordonnykh regioniv// za red. Kyfiak V.F. [Scenario forecasting of cross-border regions development// by ed. Kyfiak V.F.]. Chernivtsi: «Misto», 2017. - 329 p.

18. Ugoda pro asotsiatsiu mizh Ukrainou $\mathrm{z}$ odniei storony, ta Evropejskym Souizom, Evropejskym Spivtovarystvom z atomnoi energii I ikhnimy derzhavamychlenamy, $\mathrm{z}$ inshoi storony [Association Agreement between Ukraine, on the one hand, and the European Union, the European Atomic Energy Community, and their Member States, on the other hand]. Retrieved from https://zakon.rada.gov.ua/laws/ show/984_011/page [in Ukrainian]

19. Wassenberg B. Vivre et penser la coopération transfrontalière (Volume I): les régions frontalières françaises. -Stuttgart: Franz Steiner Verlag., 2010. 416 p.

20. Zakon Ukrainy «Pro vnesennia zmin do deyakykh zakoniv Ukrainy schodo transkordonnogo spivrobitnytstva» // Vidomosti Verkhovnoi Rady, 2018, \# 43, st.343 [Law of Ukraine «On amendments to some laws of Ukraine on cross-border cooperation»//Verkhovna Rada (BBR) Notices, 2018, No. 43, Article 433. 